\title{
Greenland, Business in the Arctic, the Polar Code and Coast Guard Cooperation
}

This issue of Arctic Review on Law and Politics represents another milestone. Even though the journal qualified for level 2 in the Norwegian Scientific Index more than a year ago, this is the first issue that effectively counts at this highest academic level for journals and books in Norway.

Originally, the majority of articles in this issue were to have related to Greenland. However, several factors, including the peer-review process and time constraints, have meant that this is not the case. Even so, there are two solid articles related to Greenland in the issue. In addition, three of the other articles deal with highly relevant topics concerning the landmasses and seas in the High North.

Maria Ackrén examines the public consultation processes followed in Greenland in connection with two large-scale mining projects, inquiring how the deliberative democratic process unfolded. The author focuses on two projects that received a lot of media attention, the 2005 Isukasia iron ore mine project and the 2001 TANBREEZ project to extract rare earth elements. These two projects used highly different approaches to public consultation. In the former case, a limited degree of deliberative democracy was used in the public consultation process, while in the latter, the opposite applies.

Peter Orebech examines the significance of historic Inuit habitation in Greenland to the outcome of the 1933 PCIJ East Greenland case. The article explains how Denmark prevented Norway from claiming East Greenland by referring to the 1814 Treaty of Kiel, which ceded Norway from Denmark to Sweden, with the significant exception of the ancient Norwegian dependencies of Greenland, Iceland and the Faroe Islands. Possession of these territories remained with the Kingdom of Denmark. Norway's attempt to annex East Greenland in 1931-32 failed because the region was not considered terra nullius, and had retained this status across the centuries. Despite the absence of any Norsemen for two centuries in the late Middle Ages, the Inuit were always considered "subjects" of the King of Denmark before, during and after this period. The study determines that a territory inhabited by indigenous groups with a form of social and political organization, precludes any claim of occupation since the land is not terra nullius. 
In addition to the two Greenland articles, this issue contains three more peerreviewed articles regarding business development, law of the sea and maritime cooperation.

Trond Nilsen and Stig Karlstad examine the challenges faced by Arctic firms in three sectors of business in Northern Norway, focusing on the bottlenecks that have prevented these sectors from gaining new market positions through the interplay of these regional firms and agencies with the Global Production Network (GPN). In the construction sector, public policy instruments are important, but not sufficiently adapted to the challenges these firms face. While the petroleum sector receives support and backing from regional agencies in order to connect to GPN, the wind power sector is actively hindered by the same agencies. The former have the opportunity to take part in new regional path creation; the latter have experienced a lack of strategic cooperation and face the risk of reducing strategic couplings to GPN, leading to path-dependent processes that lock these firms into traditional and low-tech sectors.

Oystein Fensen studies the International Code for Ships Operating in Polar Waters the Polar Code - which is the most recent instrument specifically designed to make navigation in polar waters safer and more environmentally friendly. After examining the legislative history and main contents of the Code as regards its regulations on safety measures and pollution prevention, the author places the new framework into the broader context of international law, including an examination of the Polar Code's relationship to specific provisions and legislative arrangements of the United Nations Convention on the Law of the Sea.

Andreas Osthagen examines how Norway, the United States and Russia have developed bilateral coast guard regimes in the High North since the 1970s, and subsequently how these regimes have come to constitute the backbone of managing these vast and invaluable maritime domains. He determines that the conflict in Ukraine in 2014 did not affect coast guard cooperation in the Bering and Barents Seas, and proceeds to examine why. The argument made is that the specific character of coast guards and their role as stewards of the sea separate them from other military structures, making bilateral cooperation not only valuable, but indispensable, to the management of the states' maritime sovereignty.

Arctic Review on Law and Politics aims to be a space for academic debate over issues related to the Arctic and the High North. In this issue, we are pleased to present a debate article by Ari Martin Laakso that focuses on requirements for enrollment in the Sámi electoral register in Finland. The article is a rebuttal to an article by Antti Aikio and Mattias Ährén, published in Arctic Review on Law and Politics in 2014. 